\title{
NECROTIZING FASCIITIS IN OBSTETRIC PRACTICE: REVIEW OF LITERATURE AND DESCRIPTION OF OWN CLINICAL CASE
}

\author{
V. M. Husiev, V. M. Astakhov, S. A. Dubyna (Liman, Ukraine) \\ Donetsk National Medical University
}

\begin{abstract}
Despite the successes of modern medicine, the problem of purulent surgical infection still remains relevant and is one of the unsolved and most debatable in clinical surgery. In the structure of purulentinflammatory diseases of soft tissues, there are forms of surgical infections that are characterized by progressive necrosis of fascial formations and particular clinical course. They are accompanied by the development of endotoxemia, which further leads to the development of severe sepsis and multiple organ failure. Among generalized surgical infections, necrotizing fasciitis is of particular interest one of the varieties of a large group of surgical infections of soft tissues, in the pathomorphological basis of which lies the rotten-necrotic lesion of the superficial fascia and subcutaneous fatty tissue. It has various clinical manifestations, the absence of specific signs that make it difficult for clinicians of various specialties to diagnose in time, the development of serious complications and deaths. The basis for the early diagnosis of necrotizing soft tissue infections, therefore, the key to successful treatment of these seriously ill patients, as before, is the timely analysis of anamnestic data and clinical symptoms. The treatment of necrotizing fasciitis is a difficult and complex task, which is explained by the peculiarity of the pathological process, the success of which is determined by early diagnosis and urgent radical surgical intervention. Rarely rare publications on this issue are the cause of the information vacuum and the lack of awareness of the majority of doctors in this pathology, potential for the development of critical states, once again necessitates the imperative informing of narrow specialists, as well as doctors practicing in the outpatient network and hospital level. The article describes the own clinical observation of the fulminant form of necrotising fasciitis diagnosed by autopsy data.
\end{abstract}

Key words: necrotizing infections of soft tissues; necrotizing fasciitis; lethal outcome.

ІСТОРІЯ МЕДИЦИНИ

\section{АКТУАЛЬНІ ПИТАННЯ ОХОРОНИ ЗДОРОВ'Я ЖИТЕЛІВ ЧЕРНІГІВЩИНІ, ЗАЙНЯТИХ У СІЛЬСЬКОМУ ГОСПОДАРСТВІ, В 1960-1980 рр.}

Кафедра педагогіки та психології (зав. - проф. С. Б. Пономаревський) Чернігівського обласного інституту післядипломної педагогічної освіти ім. К. Д. Ушинського <Lidlav@ukr.net>

Стаття присвячена дослідженню розвитку лікувально-санітарної допомоги в системі охорони здоров'я Украӥни, зокрема працівникам сільського господарства Чернігівщчнни. Проведено аналіз захворюваності сільських жителів, висвітлено питання причин та профілактики професійних захворювань серед селян, формування їх медико-санітарної культури.

Ключові слова: охорона здоров'я; лікувально-санітарна допомога; професійні хвороби; працівники сільського господарства; профілактика; санітарно-епідеміологічні установи. 
Актуальність проблеми. На сучасному етапі розвитку суспільства здоров’я людини $є$ найвищою людською цінністю, бо саме воно - показник цивілізованості суспільства, головний критерій ефективності діяльності всіх його сфер. Найбільш чітко проявились як позитивні, так і негативні чинники системи охорони здоров'я М. Семашка в 1960-1980 рр. Досліджуючи питання охорони здоров'я сільських жителів в Україні, ми звернули увагу на Чернігівщину, в якій поряд 3 лікувальною справою важливе місце посідає профілактика професійних захворювань серед селян, формування їх медичної та санітарної культури.

Мета дослідження - вивчення питання охорони здоров'я жителів Чернігівщини, задіяних у сільському господарстві. Реалізація мети передбачає висвітлення питань надання лікувально-санітарної допомоги працівникам сільського господарства, причин і профілактики професійних захворювань серед селян, формування їх медико-санітарної культури.

Виклад основного матеріалу. У 1960-1980 рр. медична допомога в СРСР включала лікувальну справу, профілактичну допомогу і діагностику. Лікувальна справа в радянській системі медичної допомоги відігравала провідну роль.

У 1960-х роках в Україні було здійснено спробу відійти від практики домінування стаціонару як форми лікування та відновити ідею диспансеризації. Відповідно підвищувалася роль амбулаторій і поліклінік. Поставлені державою завдання перед охороною здоров'я включали проведення профілактичних оглядів певних верств механізаторів, тваринників, робітників, взяття на диспансерний облік хворих $з$ певними хронічними захворюваннями з метою зменшення втрат з тимчасової непрацездатності. Термін їх виконання, тобто досягнення суцільної диспансеризації, становив майже 20 років і повинен був завершитись у 1980 -х роках. Для цього було розроблено інструкції, в яких містилися обсяги та частота профілактичних оглядів і спостереження за хворими з хронічними хворобами. Визначальним у цих заходах було те, що кожний здоровий і хворий повинні був періодично, але не рідше одного разу на рік проходити обстеження у трьох-чотирьох, а то й більше фахівців. Наприкінці 1980-х років профілактичними оглядами було охоплено більше половини здорових, зокрема майже всі хворі з хронічними хворобами на Чернігівщині. Водночас посилювалась роль санітарно-профілактичних заходів, які вважали визначальними при громадській медицині - попередниці радянської системи охорони здоров'я.

Значна частина працівників ферм, машинно-тракторних парків працювали в антисанітарних умовах. Професійні захворювання посідали важливе місце в структурі загальної захворюваності. Ці хвороби частіше виникали в операторів машинного доїння і механізаторів. Зокрема, в операторів машинного доїння переважали захворювання периферичної нервової системи рук: тендовагініт, неврит, міалгія, невралгія, ангіоміотрофоневроз, а також згинальні контрактури пальців, артрит, гноячкові хвороби пальців тощо. Вони нерідко призводили до тимчасової, а іноді й стійкої втрати працездатності. Були навіть випадки, коли оператори машинного доїння 3 цієї причини прагнули змінити роботу на іншу.

У 17 \% механізаторів тимчасова втрата працездатності була наслідком виникнення й періодичного загострення таких хвороб, як артро- і дорсопатія (ураження суглобів і хребта).

Фізіотерапевтичну допомогу сільським трудівникам надавали в районних та дільничних лікарнях, сільських амбулаторіях, на фельдшерсько-акушерських пунктах, але тваринники не мали змоги одержати лікувальні процедури своєчасно і в повному обсязі через те, що тваринницькі комплекси, як правило, розташовувалися на значній відстані від населених пунктів, а отже, і від лікувальних установ. Тому виникла необхідність у створенні медичних профілакторіїв для тваринників безпосередньо на цих комплексах. Такі установи були структурними частинами 
сільських лікарських дільниць і працювали під керівництвом та контролем лікарів дільничних лікарень або сільських амбулаторій. Цю форму безпосереднього наближення спеціалізованої фізіотерапевтичної допомоги до виробництва організовували на кошти колгоспів і радгоспів Чернігівщини. Основні завдання сільського медичного профілакторію визначалися спеціально розробленими методичними вказівками та інструкціями з організації й роботи колгоспного і радгоспного медичних профілакторіїв, інструкцією МОЗ УРСР «Організація лікувальної і профілактичної допомоги працівникам сільськогосподарського виробництва в умовах медичного профілакторію», наказами Міністерства охорони здоров'я СРСР № 621 від 1 червня 1984 р. «Про затвердження положення про медичний профілакторій» та № 700 від 19 червня 1984 р. «Про проведення обов’язкових попередніх при вступі на роботу і періодичних медичних оглядів трудящих, підданих впливу шкідливих і несприятливих умов праці».

Робота медичних профілакторіїв була спрямована на контроль за проведенням заходів з оздоровлення умов праці в сільському господарстві та запобігання захворюваності трудівників. Як один 3 важливих долікарських центрів охорони здоров'я профілакторій здійснював лікувально-профілактичне обслуговування, насамперед тваринників колгоспних і радгоспних молочнотоварних ферм та меха-нізаторів господарств.

Обов'язками завідувачів сільськими медичними профілакторіями були такі:

- вивчення гігієнічних умов роботи тваринників, механізаторів та інших працівників сільського господарства;

- організація періодичних медичних оглядів колгоспників і працівників радгоспів, передусім операторів машинного доїння та механізаторів;

- забезпечення проведення профілактичних курсів фізіотерапевтичних процедур за призначенням лікарів і здійснення спостереження за ефективністю лікування хворих;

- організація консультацій районних спеціалістів для хворих;

- забезпечення трудівників села першою медичною допомогою у разі травми i раптових захворювань;

- проведення серед сільськогосподарських працівників санітарно-просвітницької роботи;

- прагнення організації на тваринницьких фермах сприятливого режиму праці. Лікарі центральних районних і дільничних лікарень, проводячи щорічні медичні огляди тваринників, механізаторів та інших працівників сільського господарства, заносили в амбулаторну картку відомості про стан їхнього здоров'я i разом із завідувачем медичного профілакторію складали індивідуальний план профілактичних та лікувальних заходів.

У медичних профілакторіях застосовували світло- і теплолікування, електротерапію, масаж і лікувальну гімнастику. Для проведення процедур світлолікування використовували лампи солюкс, інфраруж, лампу Мініна, місцеві світлові ванни, ультрафіолетове опромінювання (кварц). Сприятлива біологічна дія інфрачервоних променів грунтується на тепловому ефекті, завдяки якому досягається болезаспокійливий, судинорозширювальний і тонізувальний вплив на організм пацієнтів.

Велике значення для діяльності медичних профілакторіїв мала спеціальна підготовка кадрів, проведення семінарів для лікарів сільських дільничних лікарень, районних терапевтів, фізіотерапевтів, які відповідали за роботу медичних профілакторіїв.

На курсах для працівників профілакторіїв, які періодично працювали при обласній клінічній лікарні, висвітлювалися питання стоматології і методи лікування професійних хвороб, що могли виникати у тваринників та механізаторів у разі 
порушення гігієнічних вимог до умов праці, застосування фізіотерапевтичних методів профілактики й лікування цих захворювань.

Працівники профілакторіїв проводили медичний огляд перед виїздом у рейс водіїв господарств, що сприяло їх дисциплінованості. Посилилась, набула наступального характеру санітарно-просвітницька робота в боротьбі за тверезий спосіб життя. Виготовляли та вивішували в куточках санітарно-просвітницької роботи сільських медичних профілакторіїв стенди, фотомонтажі протиалкогольного змісту.

Значну роль відігравали медичні профілакторії під час польових робіт. У цей період графік обслуговування колгоспників складали таким чином, щоб механізатори в разі захворювання могли проходити курс лікування в зручний для них час.

Через недотримання санітарних вимог до стану виробничого середовища, тобто при безпосередньому впливі на організм працівників різноманітних несприятливих виробничих чинників (пил, шум, вібрація, хімічні речовини), внаслідок тривалого перенапруження опорно-рухового та нервово-м'язового апарату, а також зараження на хвороби, що передавалися людині від тварин, могли розвинутися професійні захворювання. Так, через тривале перебування в умовах дії високих концентрацій пилу (зернового, цементного тощо) могли виникнути різні форми такої хвороби легень, як пневмоконіоз та інших захворювань дихальних шляхів; через вплив вібрації - вібраційна хвороба, шуму - неврит слухового нерва, хімічних речовин - гостре та хронічне отруєння, захворювання очей, шкіри, легень тощо.

Бруцельозом, сапом, ящуром можна було заразитися під час контакту з хворими тваринами. Професійними ці хвороби вважали в тому випадку, якщо зараження виникло під час роботи, а не поза виробничим середовищем.

Інфекційні хвороби могли розвинутися у різних працівників тваринницьких господарств, особливо у тих, хто безпосередньо обслуговував ферми, - операторів машинного доїння, тваринників, телятників, пастухів, чабанів, а також зоотехніків і ветеринарних працівників.

На жаль, на Чернігівщині в багатьох господарствах збереглися невеликі тваринницькі ферми, не обладнані у ряді випадків усім необхідним для підтримання гігієнічних умов праці, особливо для операторів машинного доїння. Загальним для таких ферм були несприятливий мікроклімат, напружена фізична праця тваринників, контакт з виділеннями тварин.

Професійним хворобам операторів машинного доїння можна запобігти, раціонально організувавши їх працю і відпочинок, усунувши дію на їхній організм шкідливих санітарно-гігієнічних факторів, здійснюючи постійний контроль за умовами виробничого середовища та станом здоров'я тваринників. Це можливо лише у разі наближення лікувальної і профілактичної допомоги до працівників тваринницьких ферм, тобто шляхом створення медичних профілакторіїв [5, C. 1-47].

Особливо важкою була праця механізаторів. Робота на тракторі вимагала постійного перевантаження. Наприклад, під час оранки частота дій важелями й педалями досягала 11-30 на 1 хв, при зусиллі на органи ручного управління - 1218 кг. На колісному тракторі за 8 год роботи сумарне зусилля становило 111 т. Лише педаль гальма вимагала одноразового навантаження на м'язи ніг 70 кг, а муфти зчеплення - 68 кг. У процесі роботи з навісними знаряддями трактористові доводилося маневрувати багатьма важелями й кількома педалями із середньою частотою 10-18 разів за 1 хв [7, С. 189]. Підприємства сільського машинобудування суттєво відставали у впровадженні до управління технікою та механізмів автоматизованих і комп'ютеризованих технологій. 
Робота на тракторах, комбайнах, автомашинах передбачала тривале сидіння в одній і тій самий позі, що призводило до перевтомлення окремих м'язів шиї, спини, живота, рук, ніг. Довготривала робота в незручному положенні погіршувала кровообіг, викликала патологічні зміни в організмі, спричинювала захворювання нервово-м'язового й опорно-рухового апарата [1, С. 4].

Більшість сільськогосподарських робіт вимагала ненормованого часу. Середня тривалість робочого дня механізатора й тваринника становила 7,5-8,5 год. У період напружених сільськогосподарських кампаній у 63 \% механізаторів вона досягала до 10 год, у 24 \% була ще вищою [8, С. 73]. Учені-економісти вважали, що праця в сільському господарстві є просто виснажливою: втома настає вже після 4 год роботи, решту часу трудівник діє через силу [13, С. 130]. Переважна більшість механізаторів фізично не мали змоги допрацювати до пенсії за спеціальністю. Безпосередньо до пенсії в деяких районах Чернігівської області допрацьовували лише 3 \% механізаторів. Решта не мали змоги переносити велике напруження, запиленість, загазованість, гуркіт тощо й переходили на вид діяльності з полегшеними умовами праці [9, С. 75].

У більшості господарств області залишався незадовільним виробничий побут. На початку 1970-х років у 85 \% господарств функціонували будинки механізаторів, але й вони не зовсім відповідали своєму призначенню - створювати працівникам умови для відпочинку, зокрема влаштування червоних куточків, ленінських кімнат, агітпунктів. Мали місце нестерпний холод, неможливість прийняти душ після брудної роботи і навіть помити руки, бо не було для цього спеціальних побутових приміщень.

Майстерні з ремонту техніки були не укомплектовані спеціальними механізмами для покращання ремонту машини, який проводили «на руках». Абсолютна більшість майстерень не опалювалась, в приміщеннях було холодно. Техніка зберігалася на подвір'ї, навіть узимку механізатори й шофери змушені були сідати в холодні кабіни, що призводило до частих простудних захворювань.

Аналогічними були умови праці на фермах. Тваринницькі приміщення мали примітивну конструкцію, не були обладнані вентиляційними пристроями та утепленням, що виклика́ло постійні протяги. Працювати в них можна було тільки в гумовому взутті. Недосконала система прибирання гною призводила до його великого скупчення в приміщеннях і поблизу них. Не було твердого покриття доріг і підходів до ферми.

У переважній кількості колгоспів і радгоспів праця залишалася ненормованою. День «розривався», оскільки доводилося три рази приходити до ферми. Побутових умов практично не було. Будинки тваринника здебільшого не функціонували, а існували тільки тому, що так вимагало начальство.

Проведена в 1965 р. спеціальними оглядовими комісіями перевірка виробничих умов на Чернігівщині виявила чимало порушень: у 151 трактора не було сигналів, у 201 - освітлення, у 22 кузнях - витяжних зондів, на 23 циркулярних пилках захисних пристроїв. У 84 випадках виявили незаземлені електродвигуни, а в 64 тваринницьких приміщеннях - непридатну до експлуатації електропроводку [12, С. 79-86]. Такий стан був типовим для більшості господарств республіки. Спостерігалася лише незначна позитивна динаміка.

Особливої шкоди здоров'ю працівникам завдавала некваліфікована робота 3 отрутохімікатами. Близько 13 \% колективних господарств не мали для них спеціальних складів, а існуючі здебільшого не відповідали промислово-санітарним вимогам (у Чернігівській - 46 \%) [11, С. 3]. Часто отрутохімікати зберігались у непристосованих для цього приміщеннях або просто надворі. До роботи з ними допускали людей без належної підготовки, спецодягу та респіраторних масок. 
Через відсутність машин, призначених для хімічної обробки рослин, іноді цю операцію здійснювали вручну.

Поширеним явищем 1960-1980-х років було залучення жінок до важкої фізичної праці. Мав місце навіть перелік сільськогосподарських робіт, на яких, як вважали, доцільніше використовувати жіночу працю. Це, зокрема, 20 видів робіт у рослинництві, 10 - у тваринництві. На думку керівників, жінки повинні були працювати на 23 видах сільськогосподарських машин, у тому числі тракторах і комбайнах. Техніка, на якій вони працювали, не була модифікованою і пристосованою для роботи жінок.

Трудівники сільського господарства частіше, ніж представники інших сфер, втрачали працездатність, отримували інвалідність. Основними причинами первинної інвалідності сільських трудівників були серцево-судинні захворювання (18 \%), травми (15\%), психоневрологічні (15\%) та онкологічні хвороби (12 \%), вироб-ничий травматизм (7 \%), інші види захворювань (33 \%) [10, С. 143]. Часто до інвалідності призводило захворювання на туберкульоз.

Високим був рівень виробничого травматизму. Лише в 1965 р. у колгоспах Чернігівської області зареєстровано 54 випадки травмування працівників із смертельними наслідками, з них 21 \% - під час дорожньо-транспортних пригод, 16 \% ремонту й обслуговування техніки, 10,2 \% - у процесі догляду за тваринами, $10 \%$ - внаслідок перекидання тракторів і комбайнів, 8,5 \% - через порушення техніки безпеки під час використання електрообладнання, $6 \%$ - на роботах у кар'єрах, 21,7 \% - за інших обставин [10, С. 143]. Аналіз структури виробничого травматизму в наступні роки свідчить про деяке його зменшення. Так, якщо пи-тома вага виробничого травматизму в 1970 р. становила 23,6 \%, то в 1986 p. $-16,8 \%$ [6, С. 93].

Аналіз причин цього явища показав, що 80 \% таких ситуацій виникало через неправильну організацію праці, відсутність належного нагляду за дотриманням техніки безпеки й трудового законодавства, незадовільну організацію навчання колгоспників безпечним прийомам праці та через порушення трудової дисципліни.

Наказ Чернігівського облздороввідділу від 7 грудня 1976 р. «Про медикосанітарне забезпечення працівників сільського господарства і осіб, залучених до сільськогосподарських робіт» передбачав ряд заходів із оздоровлення працівників до початку сільськогосподарських робіт, забезпечення якісного медичного обслуговування, перебудову графіка роботи медичних установ відповідно до графіка роботи працівників колгоспів та радгоспів [2, С. 1-4].

Одним з напрямів роботи санітарно-епідеміологічних установ був контроль за санітарним станом населених пунктів, санітарно-просвітницька робота. Наприкінці 1970-х років було охоплено навчанням з основ санітарії і гігієни 138 тис. 770 осіб. Щорічно фахівці читали близько 650 лекцій, публікувалися статті в засобах масової інформації, транслювалися передачі по радіо, демонструвалися кінофільми $з$ питань здорового способу життя, боротьби з шкідливими звичками: зловживання спиртними напоями і курінням [4, С. 1-3].

Щорічно проводили понад 15 тис. хімічних і бактеріологічних досліджень води відкритих водойм, атмосферного повітря й грунту. Працівників тваринницьких ферм та харчових підприємств зобов'язали вивчати санітарний мінімум [3, C. 21-23, 27].

Висновки. Як видно, протягом досліджуваних років продовжувала реалізовуватись концепція медичної допомоги, що включала лікувальну справу, профілактичну допомогу й діагностику. Було створено умови для підвищення культурного й санітарного рівня населення, удосконалювалася система соціального забезпечення, належним відображенням якої стала Чернігівщина. 
С пи сок лі т ератури

1. Гряник Г.Н. Охрана труда и пожарная безопасность. - К.: Выща шк., 1978. - 147 с.

2. Державний архів Чернігівської області (далі - ДАЧО), ф. Р-5153, оп. 1, спр. 741, $152 \mathrm{c}$.

3. ДАЧО, ф. Р-5153, оп. 1, спр.1395, 28 с.

4. ДАЧО, ф. Р-5153, оп. 1, спр.1427, 86 с.

5. Зленко B. I. Медичний профілакторій для працівників сільського господарства. К.: Здоров'я, 1986. -47 с

6. Из истории развития здравоохранения Черниговщины. - Чернигов: Десна, 1989. - 147 c.

7. Сальников И. И. Научно-технический прогресс и эффективность сельскохозяйственного производства. - М.: Мысль, 1974. - 325 с.

8. Формирование и развитие социалистического образа жизни на материалах Украинской ССР : Сб. науч. тр. - Днепропетровск, 1983. - 164 с.

9. Фтошов Г. С. Социально-экономические проблемы развития села. - К.: Наук. думка, 1988. - 322 с.

10. Центральний державний архів вищих органів влади та управління України (далі - ЦДАВО України) ф. Р-2, оп. 13, спр. 4683, 293 с.

11. ЦДАВО України, Ф. 342 , оп. 17, спр. 3848 , $291 \mathrm{c}$.

12. ЦДАВО України, Ф. 2605 , оп. 8 , спр. 4605 , $129 \mathrm{c}$.

13. Якимов В. Технический прогресс и воспроизводство рабочей силы в колхозах. М.: Экономика, 1976. - 151 с.
1. Gryanik G. N. Ohrana truda i pozharnaya bezopasnost'. - K.: Vyshcha shk., 1978.-147 p.

2. Derzhavnij arhiv CHernigivs'koï oblasti (dali-DACHO), f. R-5153, op. 1, spr. 741, $152 \mathrm{p}$.

3. DACHO, f. R-5153, op. 1, spr.1395, 28 p.

4. DACHO, f. R-5153, op. 1, spr.1427, 86 p.

5. Zlenko V. I. Medichnij profilaktorij dlya pracivnikiv sil's'kogo gospodarstva. - K.: Zdorov'ya, 1986. - 47 p.

6. Iz istorii razvitiya zdravoohraneniya CHernigovshchiny. - CHernigov: Desna, 1989. - 147 p.

7. Sal'nikovI.I. Nauchno-tekhnicheskijprogress i effektivnost' sel'skohozyajstvennogo proizvodstva. - M.: Mysl', 1974. - 325 p.

8. Formirovanie i razvitie socialisticheskogo obraza zhizni na materialah Ukrainskoj SSR: Sb. nauch. tr. - Dnepropetrovsk, 1983. - 164 p.

9. Ftoshov G. S. Social'no-ekonomicheskie problemy razvitiya sela. - K.: Nauk. dumka, 1988. - $322 \mathrm{p}$.

10. Central'nij derzhavnij arhiv vishchih organiv vladi ta upravlinnya Ukraïni (dali - CDAVO Ukraïni) f. R-2, op. 13, spr. 4683, 293 p.

11. CDAVO Ukraïni, F. 342, op. 17, spr. 3848 , $291 \mathrm{p}$.

12. CDAVO Ukraïni, F. 2605 , op. 8, spr. 4605 , $129 \mathrm{p}$.

13. Yakimov $V$. Tekhnicheskij progress i vosproizvodstvo rabochej sily v kolhozah. M.: Ekonomika, 1976. - 151 p.

\section{НЕКОТОРЫЕ ВОПРОСЫ ОХРАНЫ ЗДОРОВЬЯ ЖИТЕЛЕЙ ЧЕРНИГОВЩИНЫ, ЗАНЯТЫХ В СЕЛЬСКОМ ХОЗЯЙСТВЕ В 1960-1980 гг.}

\section{Л. И. Лавриненко (Чернигов)}

Статья посвящена исследованию развития лечебно-санитарной помощи в системе охраны здоровья Украины, в частности работникам сельского хозяйства Черниговщины. Проведён анализ заболеваемости сельских жителей, освещены вопросы причин и профилактики профессиональных заболеваний крестьян, формирование их медико-санитарной культуры.

Ключевые слова: охрана здоровья; лечебно-санитарная помощь; профессиональные заболевания; работники сельского хозяйства; профилактика; санитарно-эпидемиологические учреждения.

\section{SOME ISSUES OF THE HEALTH PROTECTION OF RESIDENTS OF CHERNIHIV REGION EMPLOYED IN AGRICULTURE IN 1960-1980}

\section{I. Lavrynenko (Chernihiv, Ukraine)}

Chernihiv Regional Institute of Post-graduate Pedagogical Education named after K. D. Ushinsky

The article is devoted to the study of the development of medical and sanitary care in the health care system of Ukraine, in particular, agricultural workers of the Chernihiv region. An analysis of the incidence of rural residents is carried out, the issues of causes and prevention of occupational diseases of peasants, the formation of their health culture are highlighted.

Key words: health; medical and sanitary care; occupational diseases; rural workers; prevention; sanitation and epidemiological institutions. 